\title{
AKTIVITAS ANTIFUNGI AIR PERASAN Syzygium polyanthum TERHADAP Candida albicans
}

\author{
Destri Ummi Nadziroh, Nur Candra Eka Setiawan \\ Program Studi D-III Farmasi \\ Akademi Farmasi Putra Indonesia Malang \\ Email : nur.candra.akfarpim@gmail.com
}

\begin{abstract}
Abstrak
Candida albicans adalah flora normal selaput mukosa saluran pernapasan, saluran pencernaan, dan genitalia wanita yang dapat menyebabkan sariawan, vulvovaginitis, infeksi kulit, infeksi kuku, infeksi paru-paru serta kandidiasis mukokutan menahun. Salam (Syzygium polyanthum) merupakan tanaman yang banyak dimanfaatkan sebagai bahan penyedap dalam masakan atau sebagai obat herbal seperti antifungi. Tujuan penelitian ini untuk mengetahui aktivitas antifungi air perasan Syzygium polyanthum terhadap Candida albicans. Penelitian ini dilakukan di laboratorium farmakognosi dan mikrobiologi Akademi Farmasi Putra Indonesia Malang dengan metode penelitian eksperimental. Tahap penelitian ini meliputi pembuatan air perasan Syzygium polyanthum dengan konsentrasi $100 \%$ dan 50\%, skrining fitokimia, dan dilakukan uji aktivitas antifungi terhadap Candida albicans dengan metode difusi sumuran. Hasil dari penelitian ini dapat disimpulkan bahwa air perasan dari Syzygium polyanthum tidak memiliki aktivitas antifungi dikarenakan tidak ada zona hambat yang ditandai dengan tidak adanya zona bening di sekitar lubang sumuran pada cawan petri. Perlu dilakukan penelitian lebih lanjut terhadap aktivitas antifungi dengan metode ekstraksi dengan menggunakan pelarut lain.
\end{abstract}

Kata Kunci : Antifungi, Candida albicans, Syzygium polyanthum, Perasan.

\begin{abstract}
Candida albicans is a normal flora of the respiratory tract mucous membranes, gastrointestinal tract, and female genitalia that it causes oral ulceration, vulvovaginitis, skin infections, nail infections, lung infections and chronic mucocutaneous candidiasis. Salam (Syzygium polyanthum) is a plant that is widely used as a food seasoning or as an herbal medicine such as antifungi. The purpose of this study is to know antifungal activity of water juice of bay leaf (Syzygium polyanthum) on Candida albicans. This study was conducted at laboratory pharmacognosy and microbiology Academy of Pharmacy of Putra Indonesia Malang using experimental research methods. This study steps consisted of manufacture water juice of bay leaf with $100 \%$ and $50 \%$ concentration, phytochemical screening, and then tested antifungal activity for Candida albicans using method diffusion of pit. The results of this study can be concluded that water juice of bay leaf has not antifungal activity because no inhibition zone which is indicated by the absence of clear zone around well in the petri dish. Further research is needed on antifungal activity using other extract method.
\end{abstract}

Keywords : Antifungi, Candida albicans, Syzygium polyanthum, Juice.

\section{PENDAHULUAN}

Jamur merupakan salah satu penyebab infeksi penyakit terutama di negara-negara tropis. Penyakit akibat jamur sering muncul di Indonesia. Penyebab dari infeksi jamur di Indonesia ini dikarenakan Indonesia termasuk anggota flora normal selaput mukosa saluran pernapasan, saluran pencernaan, dan genitalia wanita. Candida albicans dapat menyebabkan sariawan, vulvovaginitis, infeksi kulit, infeksi kuku, infeksi paru-paru serta kandidiasis mukokutan menahun (Jawezt et al., 1996) (Soleman dan Setiawan, 2017). Angka kejadian infeksi jamur di dunia yang disebabkan Candida negara dengan iklim tropis, udara lembab, sanitasi yang kurang, lingkungan yang padat dan tingkat sosio-ekonomi yang meningkat (Sukmawati et al., 2017). Salah satu jamur yang dapat menyebabkan infeksi adalah jamur Candida albicans. Candida albicans adalah albicans sebanyak 9.500.000 kasus per tahun (Vandeputte et al., 2011).

Dalam pengobatan antifungi dapat dilakukan terapi non farmakologi dan farmakologi. Terapi non farmakologi dapat dilakukan dengan cara menjaga kebersihan badan dan lingkungan. Sedangkan untuk terapi farmakologi dapat menggunakan alternatif pengobatan dengan bahan alam. Salah satu 
contoh bahan alam yang dapat dimanfaatkan sebagai pengobatan antifungi adalah tanaman salam.

Salam (Syzygium polyanthum) merupakan tanaman yang mudah tumbuh pada daerah tropis dan banyak tumbuh di hutan maupun ditanam di pekarangan rumah. Salam merupakan tumbuhan asli Asia Tenggara yang ditemukan di Burma, Malaysia dan Indonesia. Tanaman salam yang sering digunakan adalah bagian daun. Daun salam dalam bentuk segar maupun kering biasanya digunakan sebagai bahan penyedap dalam masakan Indonesia terutama di Sumatra, Jawa dan paling banyak di Bali (Wartini, 2009). Daun salam selain dimanfaatkan sebagai bahan penyedap makanan juga dimanfaatkan sebagai obat herbal seperti kolesterol dan asam urat (Harismah dan Chusniatun, 2016).

Menurut Silalahi (2017), daun salam diketahui mengandung flavonoid, minyak atsiri, seskuiterpen, triterpenoid, fenol, steroid, sitral, lakton, saponin, karbohidrat, dan selenium. Menurut Bhaskara (2012), ekstrak etanol daun salam mempunyai daya antifungi terhadap Candida albicans karena adanya senyawa alkaloid, flavonoid, tanin, dan minyak atsiri. Sedangkan, menurut Fitriani et. al. (2012), adanya aktivitas antifungi dari ekstrak etanol daun salam terhadap jamur Candida albicans diduga karena mengandung senyawa tanin, polifenol, flavonoid, terpenoid, alkaloid, dan sterol. Dalam penelitian ini, akan dilakukan pembuatan air perasan dengan menggunakan pelarut air karena sangat mudah diaplikasikan oleh masyarakat, dalam pembuatannya yang tidak rumit, dan semua bahan yang digunakan terjangkau untuk seluruh masyarakat.

\section{METODE PENELITIAN}

Penelitian ini termasuk jenis penelitian eksperimental.

\section{Alat dan Bahan}

Alat. Mortir dan stemper, blender (Philips), peralatan kaca (Pyrex), cawan porselen, kertas saring, alumunium foil, batang pengaduk, corong, timbangan analitik (Ohaus), autoklaf, lampu spiritus, kawat kasa, kaki tiga, oven, kapas, kertas coklat, label, lemari pendingin, inkubator, LAF (Laminar Air Flow), jarum ose, preparat glass dan cover glass, pipet tetes, mikropipet, mikroskop digital (Olympus), spektrofotometer, kuvet, cawan petri, cork borer, jangka sorong.

Bahan. Daun salam, aquades, serbuk Mg, $\mathrm{HCl}(\mathrm{p})$, pereaksi wagner, pereaksi mayer, $\mathrm{HCl} 2 \mathrm{M}, \mathrm{FeCl}_{3} 1 \%, \mathrm{FeCl}_{3} 5 \%$, Candida albicans, Sabouraud Dextrose Agar (SDA), Mueller Hunten Agar (MHA), glukosa, metylen blue.

\section{Tahap Penelitian}

Tahapan dalam penelitian ini sebagai berikut:

1. Pembuatan media untuk peremajaan Candida albicans dan uji antifungi, kemudian dilakukan sterilisasi media dan alat yang akan digunakan.

2. Melakukan peremajaan Candida albicans dengan media Sabouraud Dextrose Agar (SDA).

3. Identifikasi Candida albicans secara makroskopis dan mikroskopis dengan metylen blue dan dilihat dimikroskopis.

4. Pembuatan suspensi Candida albicans dengan media $\mathrm{NaCl} 0,9 \%$ dan diukur kekeruhannya dengan spektrofotometer dengan panjang gelombang $530 \mathrm{~nm}$.

5. Pembuatan air perasan daun salam segar dengan cara dipotong-potong kecil dan ditumbuk, kemudian diblander dengan penambahan aquadest $(1: 3)$.

6. Skrining fitokimia air perasan secara kualitatif menggunakan uji reaksi warna dan pengendapan.

7. Uji aktivitas antifungi menggunakan teknik pour plate dengan metode sumuran. diambil $1 \mathrm{~mL}$ suspensi Candida albicans, kemudian dimasukkan dalam cawan petri, ditambahkan dengan media Mueller Hunten Agar (MHA) + glukosa, dihomogenkan dan ditunggu sampai memadat. Dibuat lubang sumuran dan diberikan larutan uji dari air perasan daun salam dengan konsentrasi $100 \%$ dan $50 \%$. Diinkubasi dengan suhu $37^{\circ} \mathrm{C}$ selama 24-72 jam dan diukur zona bening sekitar sumuran. 


\section{HASIL DAN PEMBAHASAN}

Penelitian ini menggunakan daun salam yang diperoleh dari Materia Medica Batu. Daun salam segar diekstrak dengan pelarut air untuk mendapatkan hasil air perasan. Tahap penelitian ini meliputi pembuatan air perasan dari daun salam, kemudian air perasan tersebut dilakukan uji identifikasi fitokimia, dan dilakukan uji aktivitas antifungi dengan metode difusi sumuran menggunakan jamur Candida albicans.

Air perasan daun salam diperoleh dari daun salam segar yang dihaluskan di mortir kemudian diblender dan ditambah dengan aquadest. Hasil organoleptis dari air perasan diperoleh berwarna hijau bening, bau khas daun salam, dan bentuknya cair. Hasil ekstrak yang didapatkan dapat dilihat pada Tabel 1. Prosedur penelitian pembuatan air perasan menggunakan literatur Ardelia et al. (2010), air perasan daun salam yang diperoleh dari 500 gram tanpa menggunakan pelarut air mendapatkan volume air perasan $60 \mathrm{~mL}$, sedangkan menurut Geovani (2012), air perasan yang dibuat adalah dengan menggunakan pelarut akuades dengan perbandingan 1:1, tetapi daun salam pada penelitian ini saat diblender tidak bisa hancur sehingga dimodifikasi menjadi perbandingan 1:3. Hasil ekstrak yang diperoleh dari air perasan lebih banyak, sehingga akan mempengaruhi kadar dari senyawa daun salam.

Uji fitokimia dilakukan untuk mengidentifikasi senyawa yang terdapat dalam air perasan daun salam. Uji fitokimia yang dilakukan meliputi uji flavonoid, alkaloid, saponin, tanin, dan fenol. Menurut Silalahi (2017), daun salam diketahui mengandung senyawa flavonoid, minyak atsiri, seskuiterpen, triterpenoid, fenol, steroid, sitral, lakton, saponin, karbohidrat, dan selenium. Ekstrak etanol dari daun salam menurut Fitriani et.al. (2012) terdapat aktivitas antifungi karena mengandung senyawa antifungi yaitu senyawa alkaloid, flavonoid, tanin, minyak atsiri, polifenol, terpenoid, dan sterol. Hasil pengujian skrining fitokimia air perasan daun salam dapat dilihat pada Tabel 2.

Tabel 1. Hasil Air Perasan Daun Salam

\begin{tabular}{ccc}
\hline Pelarut & Massa Sampel $(\mathbf{g})$ & Hasil Ekstrak $(\mathbf{m L})$ \\
\hline Aquadest & 21 & 53 \\
\hline
\end{tabular}

Tabel 2. Hasil Skrining Fitokimia Air Perasan Daun Salam

\begin{tabular}{lll}
\hline $\begin{array}{c}\text { Metabolit } \\
\text { Sekunder }\end{array}$ & \multicolumn{1}{c}{ Literatur } & \multicolumn{1}{c}{ Hasil } \\
\hline Flavonoid & Warna kuning, orange dan merah & Warna orange jernih $(+)$ \\
\hline \multirow{2}{*}{ Alkaloid } & $\begin{array}{l}\text { Endapan warna putih atau } \\
\text { kuning }\end{array}$ & Endapan putih (+) \\
\cline { 2 - 3 } Saponin & Endapan warna coklat & Endapan orange (-) \\
\hline Tanin & $\begin{array}{l}\text { Warna stabil } \\
\text { kehitaman }\end{array}$ & Busa stabil (+) \\
\hline Fenol & $\begin{array}{l}\text { Warna biru tua atau hijau } \\
\text { kehitaman }\end{array}$ & Warna hitam $(+)$ \\
\hline
\end{tabular}

Skrining fitokimia dilakukan secara kualitatif menggunakan uji reaksi warna dan pengendapan. Dalam proses ekstraksi, senyawa aktif dalam suatu tanaman akan mudah terlarut atau terikat oleh pelarut sesuai dengan sifat kepolarannya. Sehingga larutan air yang bersifat polar akan lebih mudah mengesktrak senyawa flavonoid 
dalam jaringan tanaman. Hal ini sesuai dengan prinsip "like disolve like" dimana larutan yang bersifat polar akan berikatan dengan senyawa polar lainnya begitu pula sebaliknya, larutan yang bersifat nonpolar akan mengikat senyawa nonpolar (Agustina et al., 2016).

Uji senyawa alkaloid pada perasan menunjukkan hasil positif dengan pereaksi mayer. Pereaksi mayer mengandung kalium iodida dan merkuri(II) klorida akan bereaksi membentuk endapan merah merkurium(II) iodida. Jika kalium iodida yang ditambahkan berlebih maka akan terbentuk kalium tetraiodomerkurat(II). Pada uji alkaloid dengan pereaksi mayer akan terjadi reaksi antara nitrogen dengan ion kalium $\left(\mathrm{K}^{+}\right)$membentuk kompleks kalium alkaloid yang mengendap (Agustina et al., 2016).

Uji senyawa saponin dari perasan ditandai dengan terbentuknya busa yang stabil yaitu busa terbentuk setinggi $\pm 1 \mathrm{~cm}$ dalam waktu \pm 10 menit dan saat ditetesi dengan asam klorida ( $\mathrm{HCl}) 2 \mathrm{M}$ busa yang terbentuk tidak hilang. Terbentuknya busa pada hasil uji ini menunjukkan adanya glikosida yang mempunyai kemampuan membentuk buih dalam air (Agustina et al., 2016).

Uji senyawa tanin dan fenol dari perasan menunjukkan hasil positif dengan Candida albicans pada media Sabouraud Dextrose Agar secara makroskopik terlihat jamur yang menunjukkan tipikal kumpulan mikroorganisme yang tampak seperti krim putih dan licin disertai bau khas/yeast odour.

Identifikasi secara mikroskopis dengan metode pewarnaan sederhana menggunakan metylen blue menunjukkan jamur yang berbentuk bulat memanjang dengan menggunakan mikroskop pada perbesaran 100X. Menurut Agnita et al. (2014), identifikasi Candida albicans secara adanya perubahan warna. Pada uji ini digunakan perekasi $\mathrm{FeCl}_{3}$ untuk mengidentifikasi adanya tanin dan fenol dalam sampel. Perubahan warna menjadi hijau kehitaman terjadi akibat pembentukan senyawa kompleks antara tanin dengan $\mathrm{FeCl}_{3}$. Tanin merupakan golongan polihidroksi fenol (polifenol) yang dapat dibedakan dari fenol lain karena kemampuannya mengendapkan protein (Agustina et al., 2016).

Sebelum dilakukan identifikasi Candida albicans dilakukan peremajaan Candida albicans dengan media Sabouraud Dextrose Agar karena media Sabouraud Dextrose Agar merupakan media yang selektif untuk fungi dan yeast, sehingga dapat melihat pertumbuhan dan mengidentifikasi Candida albicans yang mempunyai $\mathrm{pH}$ asam/pH 5,6 (Mutiawati, 2016).

Berdasarkan hasil dari penelitian ini, pertumbuhan Candida albicans pada media Sabouraud Dextrose Agar setelah diinkubasi selama 24 jam dengan suhu $37^{\circ} \mathrm{C}$ secara makroskopis menunjukkan koloni berwarna putih dan berbentuk krim yang menonjol diatas media. Menurut Mutiawati (2016), pertumbuhan

mikroskopik dilakukan dengan cara pewarnaan sederhana dengan menggunakan metylen blue (Wijayanti \& Susilowati. 2017), berdasarkan hasil pewarnaan, jamur yang diamati di bawah mikroskop berbentuk bulat (yeast) dan panjang (hifa), hal ini sesuai dengan karakteristik Candida albicans yang memiliki 2 bentuk yaitu yeast dan hifa. Maka dapat disimpulkan jamur yang tumbuh pada media Sabouraud Dextrose Agar positif jamur Candida albicans. 


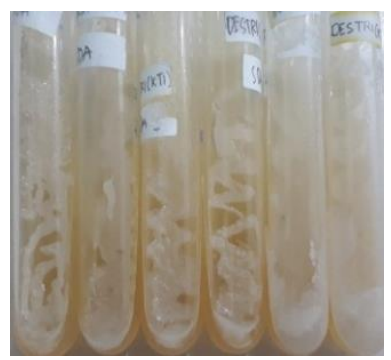

(a)

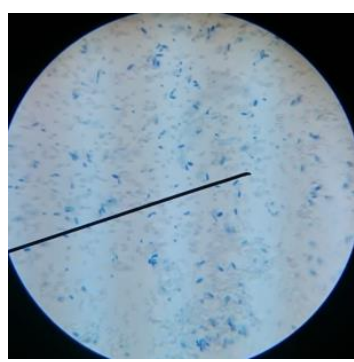

(b)

Gambar 1. (a) Pertumbuhan Candida albicans pada media Sabouraud Dextrose Agar secara makroskopis (b) Pertumbuhan Candida albicans pada media Sabouraud Dextrose Agar secara mikroskopis.

Penelitian aktivitas antifungi menggunakan media Mueller Hunten Agar karena media Mueller Hunten Agar merupakan media yang digunakan untuk pengujian kerentanan mikroorganisme terhadap antimikroba dengan menggunakan metode difusi (HiMedia, 2016), sehingga perlu penambahan glukosa pada media
Mueller Hunten Agar yang dapat berperan sebagai sumber karbon dan energi bagi Candida albicans (Leepel, et al., 2009). Hasil pengujian aktivitas antifungi air perasan daun salam yang diinkubasi dan diamati selama 24 sampai 72 jam dapat dilihat pada Tabel 3.

Tabel 3. Hasil Aktivitas Antifungi Air Perasan Daun Salam

\begin{tabular}{ccccc}
\hline Konsentrasi Air & \multicolumn{3}{c}{ Diameter Zona Hambat $(\mathbf{m m})$} & Rata-rata \\
\cline { 2 - 5 } Perasan & Replikasi 1 & Replikasi 2 & Replikasi 3 & \\
\hline $100 \%$ & 0 & 0 & 0 & 0 \\
\hline $50 \%$ & 0 & 0 & 0 & 0 \\
\hline
\end{tabular}

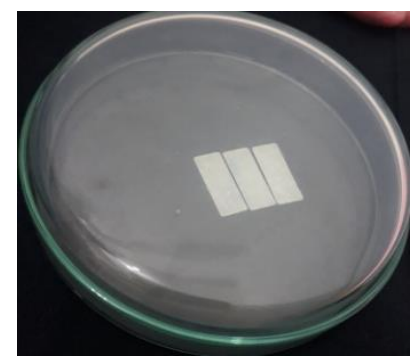

(a)

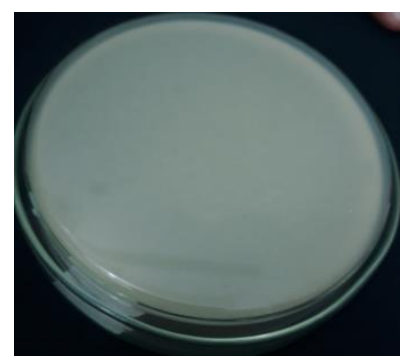

(b)

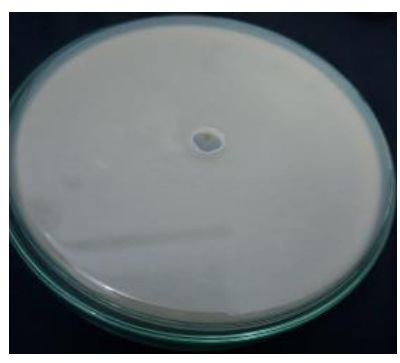

(c)

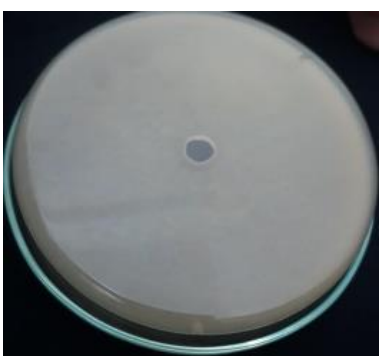

(d)

Gambar 2. (a) Kontrol Media (b) Media + Candida albicans (c) Air Perasan $100 \%$ (d) Air Perasan 50\%.

Aktivitas antimikroba dipengaruhi oleh beberapa faktor antara lain, konsentrasi atau intensitas zat antimikroba, jumlah mikroorganisme, keasaman atau kebasaan $(\mathrm{pH})$, potensi suatu zat antimikroba dalam larutan yang diuji, dan kepekaan suatu mikroba terhadap konsentrasi antibakteri (Widyarto, 2009). Parameter yang digunakan dalam penelitian uji aktivitas antifungi ini adalah diameter zona hambat yang ditandai dengan zona bening di sekitar lubang sumuran pada cawan petri.
Dari Tabel 3. menunjukkan bahwa air perasan daun salam tidak memiliki aktivitas antifungi dikarenakan rata-rata zona hambat yang diperoleh dari 2 konsentrasi tersebuat adalah $0 \mathrm{~mm}$. Hal ini karena kemungkinan senyawa antifungi seperti senyawa alkaloid, flavonoid, fenol, tanin, dan saponin yang terdapat dalam air perasan tidak bisa tersari atau terekstrak secara maksimal sehingga kadar senyawa dari air perasan menurun yang akan menyebabkan potensi dari senyawa pada air 
perasan tidak bisa maksimal untuk menghambat Candida albicans.

\section{KESIMPULAN}

Berdasarkan penelitian yang sudah dilakukan tentang aktivitas antifungi air perasan daun salam (Syzygium polyanthum) terhadap Candida albicans, dapat disimpulkan bahwa air perasan daun salam tidak memiliki aktivitas antifungi dikarenakan tidak ada zona hambat yang ditandai dengan tidak adanya zona bening di sekitar lubang sumuran pada cawan petri.

\section{DAFTAR RUJUKAN}

Agnita, Parka, J. Waluyo, D. Wahyuni. 2014. Perbedaan Daya Hambat Ekstrak Dan Rebusan Daun Jarak Pagar (Jatropha curcas L.) Terhadap Pertumbuhan Candida albicans (Robin) Berkhout. Artikel Ilmiah. Jember: Universitas Jember.

Agustina, Sry, Ruslan, A. Wiraningtyas. 2016. Skrining Fitokimia Tanaman Obat Di Kabupaten Bima. CAKRA Kimia Indonesia E-Journal of Applied Chemistry Vol 4 (1): 71-76.

Ardelia, P. I., Andrini, F., Hamidy, M. Y., 2010. Aktivitas Antijamur Air Perasan Daun Seledri (Apium graveolens L.) Terhadap Candida albicans Secara In Vitro. JIK Jilid 4 (2): 102-107.

Bhaskara, G. Y., 2012. Uji Daya Antifungi Ekstrak Etanol Daun Salam (Syzygium polianthum [Wight] Walp.) terhadap Candida albicans ATCC 10231 secara In Vitro. Skripsi. Surakarta: Universitas Muhammadiyah Surakarta.

Wijayanti, E. D. \& E. Susilowati. 2017. Eksplorasi Ekstrak Etanol Beberapa Tumbuhan Berpotensi Sebagai Antiketombe. Jurnal Riset Sains dan Teknologi. Volume 1 (2): 75-81

Fitriani, A., Hamdiyati, Y., Engriyani, R. 2012. Aktivitas Antifungi Ekstrak Etanol Daun Salam (Syzygium polyanthum (Wight) Walp.) terhadap Pertumbuhan Jamur Candida albicans secara in vitro. Biosfera Vol 29 (2): 71-79.

Geovani, Vebri. 2012. Pengaruh Perasan Daun Salam (Eugenia polyantha Wight) $80 \%$ Sebagai Pembersih Gigi Tiruan Terhadap Kekuatan Tekan Resin Akrilik Tipe HEAT-CURED Dengan Variasi Lama Perendaman. Skripsi. Jember: Universitas Jember.

Harismah, K. dan Chusniatun, 2016. Pemanfaatan Daun Salam (Eugenia polyantha) Sebagai Obat Herbal dan Rempah Penyedap Makanan. Warta LPM. Vol 19 (2): 110-118.

HiMedia. 2016. Technical Data Mueller Hinton Agar. http://himedialabs.com/TD/M173.pdf.

Jawezt, E., J. Melnick, E. Adelberg. Mikrobiologi Kedokteran. Edisi ke-20. Terjemahan oleh Edi Nugroho, R.F. Maulany. 1996. Jakarta: EGC.

Leepel, L. A., Hidayat, R., Puspitawati, R., Bahtiar, B. M. 2009. Efek Penambahan Glukosa Pada Saburoud Dextrose Broth Terhadap Pertumbuhan Candida albicans (Uji In Vitro). Indonesia Journal of Dentistry Vol 16 (1): 58-63.

Mutiawati, Vivi Keumala. 2016. Pemeriksaan Mikrobiologi pada Candida albicans. Jurnal Kedokteran Syiah Kuala Vol 16 (1): 53-63.

Candida albicans. Skripsi. Jakarta: UIN Syarif Hidayatullah Jakarta.

Rizki, M. I. dan E. M. Hariandja. 2015. Aktivitas Farmakologis, Senyawa Aktif, dan Mekanisme Kerja Daun Salam (Syzygium polyanthum). Prosiding Seminar Nasional \& Workshop "Perkembangan Terkini Sains Farmasi \& Klinik 5", Padang, 6-7 November. 
Rizki, A. U., Cholid, A. R., M. Amalia. 2016. Perbedaan Efektivitas Ekstrak Rimpang Temulawak (Curcuma xanthorriza Roxb.) Dengan Ekstrak Daun Salam (Eugenia polyantha Wight) Pada Penurunan Kadar Kolesterol Total Tikus Putih Jantan (Rattus norvegicus). Jurnal Profesi Medika Vol 10 (1): 54-69.

Silalahi, Mariana. 2017. Syzygium polyanthum (Wight) Walp. (Botani, Metabolit Sekunder dan Pemanfaatan). J D P Vol 10 (1): 1-16.

Sukmawati, I. K., D. Purnamaasri, Suwendar. 2017. Aktivitas Antijamur Ekstrak Etanol dan Fraksi Daun Kemangi (Ocimum Sanctum L.) Terhadap Jamur Candida albicans, Microsporum gypseum, dan Aspergillus flavus. Jurnal Farmasi Galenika Vol 3 (1): 30-35.

Soleman, Dahlisa dan Setiawan, N.C.E. 2017. Aktivitas Antifungi Ekstrak Metanol Kulit Batang Jambu Mete terhadap
Candida albicans. Journal Cis-Trans (JC-T) Volume 1, Nomor 2

Wartini, N. M., 2009. Senyawa Penyusun Ekstrak Flavor Daun Salam (Eugenia polyantha Wight) Hasil Distilasi Uap Menggunakan Pelarut n-Heksana dan Tanpa n-Heksana. Jurnal Agrotekno Vol 15 (2): 72-77.

Widyarto, A. N., 2009. Uji Aktivitas Antibakteri Minyak Atsiri Daun dan Jeruk Kepok (Citrus nobilis Lour.) Terhadap Staphylococcus aureus dan Escherichia coli. Skripsi. Surakarta: Universitas Muhammadiyah Surakarta.

Vandeputte, Patrick., Ferrari, Selene., and Coste,Alix T. 2011. Antifungal Resistance and New Strategies to Control Fungal Infections. International Journal of Microbiology Volume 2012, Article ID 713687, 26 pages 